\title{
Generation of Volatile Compounds from Carotenoids of Dunaliella bardawil Algae by Water Bath Heating and Microwave Irradiation
}

\author{
Natália A. B. Tinoco, ${ }^{a}$ Thais M. Uekane, ${ }^{a}$ Anna Tsukui, ${ }^{a}$ Paula F. de Aguiar, ${ }^{a}$ \\ Cláudia M. L. L. Teixeira ${ }^{b}$ and Claudia M. Rezende ${ }^{*, a}$
}

\author{
${ }^{a}$ Instituto de Química, Universidade Federal do Rio de Janeiro, 21945-970 Rio de Janeiro-RJ, Brazil \\ ${ }^{b}$ Instituto Nacional de Tecnologia, 20081-312 Rio de Janeiro-RJ, Brazil
}

\begin{abstract}
The volatile compounds formed by thermal degradation of the carotenoids present in Dunaliella bardawil were investigated by microwave irradiation (MW) and water bath heating (WB) in different conditions of temperature and time using central composite design. Volatiles extraction by solid phase microextraction (SPME) was optimized and performed at $40{ }^{\circ} \mathrm{C}$ for 15 minutes, and those in greater amount were quantified by a validated method of gas chromatography coupled to a quadrupole mass spectrometer (GC-qMS). Employing WB, 10, 12 and $120 \mathrm{ng} \mathrm{mL}^{-1}$ of $\beta$-cyclocitral, $\alpha$-ionone e $\beta$-ionone, respectively, were obtained between 60 and $87^{\circ} \mathrm{C}$ for $30-75 \mathrm{~min}$, while by $\mathrm{MW}, 5,5,50 \mathrm{ng} \mathrm{mL}{ }^{-1}$ were obtained between $75-107{ }^{\circ} \mathrm{C}$ for $1.5-2.8 \mathrm{~min}$. Considering the shorter time of MW, it can be concluded that if the time necessary to obtain the best yield by WB is employed in multiple MW cycles, an amount 10 times greater of those compounds would be obtained by MW than by WB. The results suggest a new biotechnology application for the carotenoids of the microalgae of the Dunaliella genus.
\end{abstract}

Keywords: Dunaliella bardawil, $\beta$-cyclocitral, ionone, carotenoid, microwave, water bath

\section{Introduction}

Microalgae are photosynthetic microorganisms widely distributed in marine, freshwater and terrestrial ecosystems. ${ }^{1,2}$ They produce a great diversity of compounds with high commercial value, such as polyunsaturated fatty acids, carotenoids, phycobilins, polysaccharides, vitamins and sterols. ${ }^{3-7}$ The production of microalgae supplies the cosmetic and food supplement industries, and boosts the development of natural food products, an emerging and promising field for industrial application. ${ }^{8}$ Microalgae have properties typical of higher plants (efficient oxygenic photosynthesis and simplicity of nutritional requirements), but also biotechnological attributes of microbial cells (rapid growth in culture medium and capacity to accumulate or secrete metabolites of interest), ${ }^{4}$ supporting large scale applications.

Among the microalgae used to obtain carotenoids, two species of the genus Dunaliella, D. bardawil and $D$. salina stand out for the production of $\beta$-carotene in their chloroplasts. ${ }^{9}$ The accumulation capacity of $\beta$-carotene in

*e-mail: claudia.rezendeufrj@gmail.com
Dunaliella is influenced by stress factors in culture, such as high light intensity and salt concentration, low temperatures and/or nitrate deficiency. ${ }^{10}$ Studies reported in the literature aimed at increasing the production of carotenoids in Dunaliella showed that its concentration varies in a range between 4 and $38 \mu \mathrm{g} \mathrm{mL}^{-1}$. $^{11-14}$

Herrero et al. ${ }^{15}$ evaluated the chemical composition and antimicrobial activity of the pressurized extract of $D$. salina. Norisoprenoids such as $\alpha$-ionone, $\beta$-ionone and $\beta$-cyclocitral, besides neophytadiene and phytol were observed, as well as antimicrobial activity associated to volatiles. Previously, Larrouche et al. ${ }^{16}$ showed that $\beta$-ionone inhibits the respiratory chain, preventing microbial oxygen consumption.

Norisoprenoids can be formed from carotenoids by external agents such as temperature, light, and acidity change, or by enzyme/microbial action. ${ }^{17-20}$ The oxidation of $\beta$-carotene results in epoxides, apocarotenals and apocarotenones, which in later stages of oxidation produce lighter carbonyl compounds such as norisoprenoids. ${ }^{21}$ However, the production of aroma compounds from plants is a low-yield process, and the main source is from synthesis. ${ }^{22,23}$ On the other hand, biotechnological processes 
usually involve less environment damage than chemical processes, and can favor stereospecific flavors.

A preliminary evidence that Dunaliella might be useful in biotechnological processes for aroma production was obtained by Donadio et al. ${ }^{24}$ investigating the sea salt known as "Fleur de sel", the solar salt of Saint-Armel (Brittany, France), a valuable spice in international cuisine. The authors suggested that, in addition to its pale orange color influenced by the carotenoid content of the sea algae, the flavor of the salt could be correlated to the norisoprenoids formed from the Dunalliela carotenoids.

Microwave irradiation is widely known as an alternative tool to conventional methods of synthesis and extraction, for instance, microwave-assisted extraction (MAE) can substitute Soxhlet extraction, ${ }^{25}$ ultrasound and simple heating reflux. In food processing, microwave irradiation has been successfully applied in pasteurization, decontamination and disinfection. ${ }^{26,27}$

Thus, the aim of this study was to investigate the formation of volatile compounds from the controlled degradation of carotenoids present in D. bardawil microalgae by microwave irradiation versus water bath heating.

\section{Experimental}

\section{Cultivation conditions of Dunaliella bardawil}

Microalgae D. bardawil (UTEX LB 2538, University of Texas) cultivation was performed using the culture medium developed by Shaish et al..$^{28}$ at $\mathrm{pH} 8.5$ and agitation at $180 \mathrm{rpm}$ in an orbital shaker table at $25{ }^{\circ} \mathrm{C}( \pm 3)$. Cultivation was carried out in two stages, in order to obtain a biomass rich in carotenoids, according to previous studies of our group (data not shown). To maximize cell growth, cultivation was carried out with a constant light intensity of $150 \mu \mathrm{E} \mathrm{m}^{-2} \mathrm{~s}^{-1}$ (fluorescent lamps of $59 \mathrm{~W}$ ). After the culture achieved the stationary growth phase $\left(6 \times 10^{-5}\right.$ cells $\left.\mathrm{mL}^{-1}\right)$, it was centrifuged at $3500 \mathrm{rpm}$, at $15^{\circ} \mathrm{C}$ for $15 \mathrm{~min}$. The supernatant was discarded and the green cell pellet (GP) resuspended in $300 \mathrm{~mL}$ of culture medium (without $\mathrm{NaNO}_{3}$ ). In the second stage performed to promote the accumulation of $\beta$-carotene, the culture remained for $72 \mathrm{~h}$ under stirring and light intensity of $400 \mu \mathrm{E} \mathrm{m}^{-2} \mathrm{~s}^{-1}$. Then, aliquots of $10 \mathrm{~mL}$ of biomass rich in carotenoids (BC1) were stored in $15 \mathrm{~mL}$ tubes with Shaish medium in a freezer until the moment of analysis, when the biomass was thawed and centrifuged at $3500 \mathrm{rpm}$, at $15^{\circ} \mathrm{C}$ for $15 \mathrm{~min}$. The supernatant (Shaish medium) was discarded and the orange cell pellet (OP) resuspended in $10 \mathrm{~mL}$ of sterile distilled water, and then transferred to
$40 \mathrm{~mL}$ vials with cover and silicone septum. The biomass rich in carotenoids with distilled water (BC2) was used to evaluate the controlled degradation of carotenoids in water bath and microwave controlled conditions.

\section{Solid phase microextraction (SPME)}

The experimental conditions of solid phase microextraction (SPME) were optimized to monitor the production of volatile compounds in the biomass (BC2) process. A central composite factorial design with five levels was employed (Table 1). The volatile compounds were trapped on a divinylbenzene/carboxen/ polydimethylsiloxane (DVB/CAR/PDMS) SPME fiber and analyzed by gas chromatography coupled to a quadrupole mass spectrometer (GC-qMS).

Table 1. Experimental design matrix for SPME

\begin{tabular}{lcc}
\hline Experiment & Temperature $/{ }^{\circ} \mathrm{C}$ & time $/$ min \\
\hline 1 & 30 & 30 \\
2 & 40 & 15 \\
3 & 40 & 45 \\
4 & 60 & 9 \\
5 & 60 & 51 \\
$\mathrm{CP}$ & 60 & 30 \\
$\mathrm{CP}$ & 60 & 30 \\
6 & 80 & 15 \\
7 & 80 & 45 \\
8 & 88 & 30 \\
\hline
\end{tabular}

CP: central point.

Statistica software version 7 (2004) was used to process the analyses results. Each experiment was performed in triplicate.

\section{GC-qMS analysis}

GC-qMS was conducted on an Agilent chromatograph (6850) coupled to a mass detector (5975C) system, equipped with a DB- 1 capillary column $(30 \mathrm{~m} \times 0.25 \mathrm{~mm} \times 0.25 \mu \mathrm{m})$, operated in electron ionization (EI) mode at $70 \mathrm{eV}$ over a $50-550 \mathrm{~m} / \mathrm{z}$ range. Selective ion monitoring (SIM) of $\alpha$-ionone, $\beta$-ionone and $\beta$-cyclocitral $(\mathrm{m} / \mathrm{z} 41,91,93,121$, $136,137,152,177,192)$ was performed. Helium was used as carrier gas at $1.5 \mathrm{~mL} \mathrm{~min}^{-1}$. Oven temperature ranges were $35-130{ }^{\circ} \mathrm{C}\left(6{ }^{\circ} \mathrm{C} \min ^{-1}\right), 130-160{ }^{\circ} \mathrm{C}\left(3.5^{\circ} \mathrm{C} \min ^{-1}\right)$ and $160-250{ }^{\circ} \mathrm{C}\left(35^{\circ} \mathrm{C} \mathrm{min}{ }^{-1}\right.$, kept for 2 min at $\left.250{ }^{\circ} \mathrm{C}\right)$. All analyses were performed in splitless injection mode. The injector temperature, source of quadrupole and transfer zone were: 250,230 and $150{ }^{\circ} \mathrm{C}$, respectively. 
Linear retention index (LRI) of the compounds, ${ }^{29,30}$ standards co-injection and comparison with NIST 2008 library database were used to confirm compound identity.

\section{Quantification of $\beta$-cyclocitral and ionones}

The parameters evaluated in the determination of the concentration of the major volatiles, were: selectivity, linearity, range, limit of detection (LOD) and quantification (LOQ), accuracy and precision (repeatability), in accordance to Instituto Nacional de Metrologia, Normalização e Qualidade Industrial (INMETRO). ${ }^{31}$ The analytical curves of $\beta$-cyclocitral and $\alpha$-ionone were built by using aqueous solutions fortified with standards.

To determine selectivity, matrix effect was investigated for $\beta$-cyclocitral and $\alpha$-ionone by comparing their curves in solution (water and ethanol) and matrices (cell suspension of $D$. bardawil added with $\beta$-cyclocitral and $\alpha$-ionone, in both solvents) and the slopes of two regression lines. ${ }^{32}$ After determining the matrix effect, linearity was verified by the presence of outliers, by Grubb's test, and homoscedasticity by Cochran's test. The determination coefficient and the residual plot were then obtained.

From a stock solution of $\beta$-cyclocitral and $\alpha$-ionone (36.7 and $35.7 \mu \mathrm{g} \mathrm{mL}^{-1}$, respectively), aqueous standard solutions were prepared with the following concentrations: $1,3,5,10,15 \mathrm{ng} \mathrm{mL}^{-1} ; 1,30,60,90$, $150 \mathrm{ng} \mathrm{mL}^{-1}$, respectively. Each solution was analyzed by HS-SPME/GC-qMS. First, the cell suspension of $D$. bardawil in water was placed in a $40 \mathrm{~mL}$ vial and standard solutions added (final volume of $10 \mathrm{~mL}$ ). Then, SPME fiber was manually exposed in the vial headspace under the conditions determined by the central composite factorial design. All measurements were made in three replicates, each replicate being the analysis of a different aliquot of each aqueous solution.

Accuracy was determined through the recovery of $\beta$-cyclocitral and $\alpha$-ionone and precision through repeatability. LOD and LOQ were obtained by injecting $\beta$-cyclocitral and $\alpha$-ionone until a signal to noise ratio equal to 3 and 10 , respectively.

\section{Quantification of carotenoids}

Total carotenoid content was measured in the $\beta$-carotenerich biomass (BC2). The biomass was extracted with ethanol (95\%) and spectrophotometrically measured by the method of Lichtenthaler. ${ }^{33}$ Carotenoid profile was obtained by HPLC-UV (460 nm) after separation in a Nova Pak C-18 analytical column according to Brotas and Plante-Cuny ${ }^{34}$ related to standards.
Controlled degradation of carotenoids from $D$. bardawil by water bath heating and microwave irradiation

In order to evaluate the influence of time and temperature on the degradation of the carotenoids present in $D$. bardawil biomass (BC2), a central composite design with two variables was used, in which five levels of temperature were employed for both water bath heating (WB) and microwave irradiation (MW) processes (Table 2). Each experiment was made in triplicate, using $10 \mathrm{~mL}$ of sample BC2. Statistica software version 7 (2004) was used for data analysis.

Table 2. Matrix of experiments for water bath heating (WB) and microwave irradiation (MW) controlled degradation of $D$. bardawil biomass (BC2)

\begin{tabular}{lccc}
\hline Experiment & Temperature $/{ }^{\circ} \mathrm{C}$ & $\begin{array}{c}\text { WB } \\
\text { time } / \text { min }\end{array}$ & $\begin{array}{c}\text { MW } \\
\text { time } / \text { min }\end{array}$ \\
\hline 1 & 70 & 15.0 & 0.5 \\
2 & 70 & 75.0 & 2.5 \\
3 & 100 & 15.0 & 0.5 \\
4 & 100 & 75.0 & 2.5 \\
5 & 64 & 45.0 & 1.5 \\
6 & 106 & 45.0 & 1.5 \\
7 & 85 & 2.5 & 0.08 \\
8 & 85 & 87.0 & 2.9 \\
9 & 85 & 45.0 & 1.5 \\
10 & 85 & 45.0 & 1.5 \\
\hline
\end{tabular}

\section{Results and Discussion}

\section{SPME optimization}

In the SPME analyses of $D$. bardawil biomass, seven volatiles were identified: $\alpha$-ionone, $\beta$-ionone, $\beta$-cyclocitral, dihydroactinidiolide, 7,8-dihydro- $\beta$-ionone, 5,6-epoxy$\beta$-ionone and trans-geranyl acetone, among which $\beta$-cyclocitral, $\alpha$-ionone and $\beta$-ionone were the major compounds in all experiments performed (Supplementary Information section, Figure S1). Taking into account that carotenoid degradation depends on temperature and heating time,${ }^{24}$ and also that SPME conditions can influence volatile production, a central composite design for SPME conditions was carried out monitoring $\beta$-cyclocitral and the ionones. The response surface graphs are shown in the Supplementary Information section (Figure S2).

A considerable increase of the absolute areas of ionones occurred when SPME was carried out up to $60{ }^{\circ} \mathrm{C}$ and $40 \mathrm{~min}$. For $\beta$-cyclocitral, the increase was observed between $50-75^{\circ} \mathrm{C}$ and $35-50 \mathrm{~min}$. With the 
aid of standards, Nonier et al..$^{35}$ showed that from room temperature up to $40{ }^{\circ} \mathrm{C}$ (40 $\left.\mathrm{min}\right)$, the concentration of $\beta$-carotene suffered a reduction of only $2.5 \%$, while at $70{ }^{\circ} \mathrm{C}(20 \mathrm{~min})$ it was completely degraded. Therefore, the increase in $\alpha$ - and $\beta$-ionone areas with time and temperature does not necessarily indicate that a more effective extraction occurred, as suggested for $\beta$-cyclocitral (Supplementary Information section). In fact, higher temperatures may promote the degradation of carotenoids in D. bardawil.

Based on this, softer conditions for SPME extraction were used. At $30{ }^{\circ} \mathrm{C} / 30 \mathrm{~min}$ and $40{ }^{\circ} \mathrm{C} / 15 \mathrm{~min}$, the GC profile was equivalent for $\alpha$ - and $\beta$-ionone, suggesting that the degradation of carotenoids in $D$. bardawill biomass had not yet started. So, the last condition of $40{ }^{\circ} \mathrm{C}$ for $15 \mathrm{~min}$ was chosen due to the shorter time.

\section{Norisoprenoids quantification}

As no quantitative method for the determination of norisoprenoids obtained from carotenoids of D. bardawil has been described in literature, the parameters of validation were defined as shown in Table 3. Evaluation of the matrix effect was performed by comparing the slope of the straight line and, as $\mathrm{t}_{\text {calculated }}$ was greater than $\mathrm{t}_{\text {tabulated }}$ for $\beta$-cyclocitral (Table 3), ${ }^{32}$ a matrix effect was accepted for this compound, and extrapolated for $\alpha$-ionone.

The analytical curves and residue profile for $\beta$-cyclocitral and $\alpha$-ionone are shown in the Supplementary Information section (Figure S3). The method was successfully implemented, allowing more accurate data for the experiments aimed at the production of norisoprenoids.
Optimization of volatiles formation from $D$. bardawil biomass (BC2) by water bath heating and microwave irradiation

HPLC-UV of the carotenoids present in D. bardawil biomass showed that $90 \%$ was composed by $\beta$-carotene and $10 \%$ by lutein (Supplementary Information section, Figure S4) and total carotenoids in BC2 biomass was of $15 \mu \mathrm{g} 10 \mathrm{~mL}^{-1}$. The controlled degradation of carotenoids and the formation of $\beta$-cyclocitral, $\alpha$ - and $\beta$-ionones were evaluated in a controlled water bath heating (WB) and by microwave irradiation (MW) (Table 2, Experimental section). SPME-GC-qMS (40 ${ }^{\circ} \mathrm{C}$ for $15 \mathrm{~min}$ ) was performed, as previously discussed.

The influence of temperature and incubation time on the response variable (concentration of $\beta$-cyclocitral, $\alpha$-ionone and $\beta$-ionone from $\mathrm{BC} 2$ biomass), using MW and $\mathrm{WB}$, is shown in the contour plots of Figure 1 (response surface graphs are displayed in the Supplementary Information section, Figure S5). The concentration (ng $\left.\mathrm{mL}^{-1}\right)$ of $\beta$-cyclocitral, $\alpha$-ionone and $\beta$-ionone at the central point is shown in the Supplementary Information section, Table S1.

In SPME from D. bardawil (BC2) WB treatment, the response variable (concentration) was greater for $\beta$-cyclocitral when temperature was between $60-87{ }^{\circ} \mathrm{C}$ for 30-70 $\mathrm{min}$; for $\alpha$-ionone, it was between $65-85{ }^{\circ} \mathrm{C}$ for 30-55 $\mathrm{min}$ and for $\beta$-ionone, between $60-62{ }^{\circ} \mathrm{C}$ for 45-75 min, leading to the production of 10, 12 and $120 \mathrm{ng} \mathrm{mL}^{-1}$ of $\beta$-cyclocitral, $\alpha$-ionone and $\beta$-ionone, respectively. For MW, the response variable (concentration) was greater for $\beta$-cyclocitral between $92-107{ }^{\circ} \mathrm{C}$ for 2.3-2.8 $\mathrm{min}$, while for $\alpha$-ionone and $\beta$-ionone the best conditions were between $75-85{ }^{\circ} \mathrm{C}$ for $1.5-1.8 \mathrm{~min}$ and

Table 3. Validation parameters for $\beta$-cyclocitral and $\alpha$-ionone in GC-qMS (SIM)

\begin{tabular}{|c|c|c|}
\hline Parameter & $\beta$-Cyclocitral ${ }^{\mathrm{a}}$ & $\alpha$-Ionone ${ }^{\mathrm{a}}$ \\
\hline \multicolumn{3}{|l|}{ Linearity } \\
\hline Concentration levels / $\left(\mathrm{ng} \mathrm{mL}^{-1}\right)$ & $1,3,5,10,15$ & $1,30,60,90,150$ \\
\hline Correlation coefficient (r) & 0.9916 & 0.9947 \\
\hline \multirow[t]{3}{*}{ Cochran's test } & homoscedasticity & homoscedasticity \\
\hline & $\mathrm{C}_{\mathrm{cal}}=0.37$ & $\mathrm{C}_{\mathrm{cal}}=0.63$ \\
\hline & $\mathrm{C}_{\mathrm{tab}}=0.68$ & $\mathrm{C}_{\mathrm{tab}}=0.68$ \\
\hline \multicolumn{3}{|l|}{ Selectivity } \\
\hline $\mathrm{m} / \mathrm{z}$ & $41,81,137$ & $43,93,121$ \\
\hline \multirow[t]{3}{*}{ Matrix effect } & present & absent \\
\hline & $\mathrm{t}_{\mathrm{cal}}=2.71$ & $\mathrm{t}_{\mathrm{cal}}=1.30$ \\
\hline & $\mathrm{t}_{\mathrm{tab}}=2.05$ & $\mathrm{t}_{\mathrm{tab}}=2.05$ \\
\hline $\mathrm{LOQ} /\left(\mathrm{ng} \mathrm{mL}^{-1}\right)$ & 1.0 & 0.6 \\
\hline $\mathrm{LOD} /\left(\mathrm{ng} \mathrm{mL}^{-1}\right)$ & 0.3 & 0.2 \\
\hline \multicolumn{3}{|l|}{ Accuracy } \\
\hline Mean recovery / \% & 80.87 & 89.91 \\
\hline \multicolumn{3}{|l|}{ Precision } \\
\hline Repeatability / \% & $13-23$ & $12-15$ \\
\hline
\end{tabular}

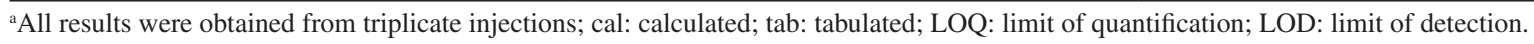


(A)

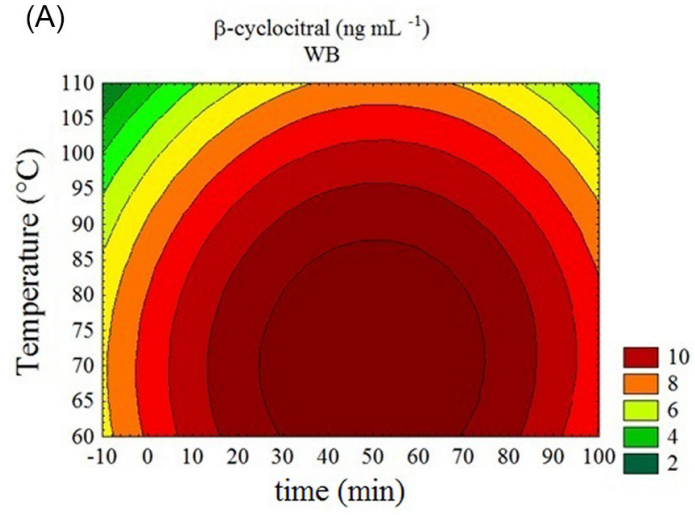

(C)

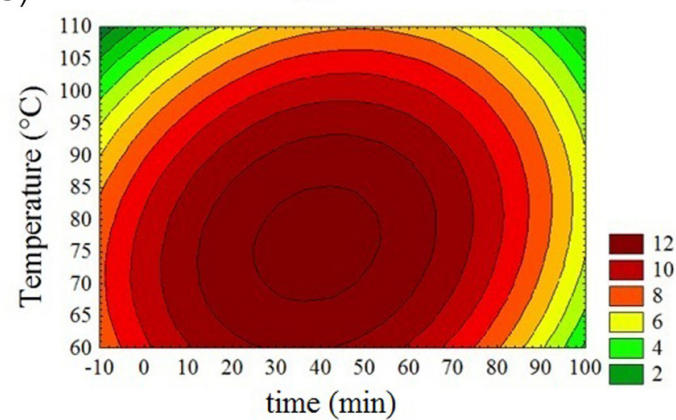

(E)

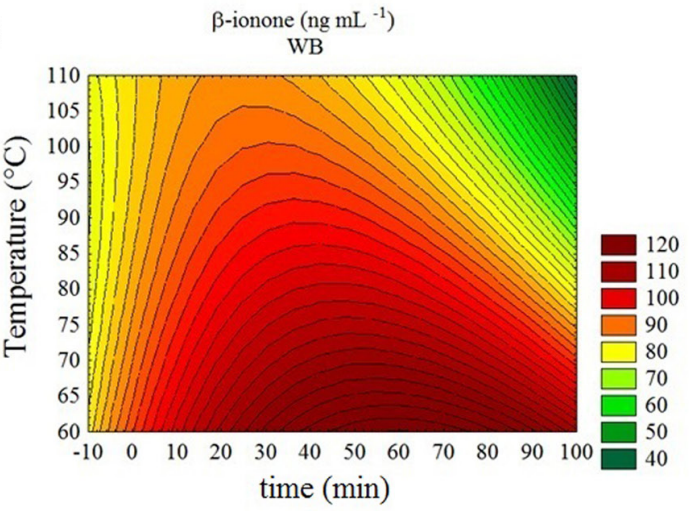

(G)

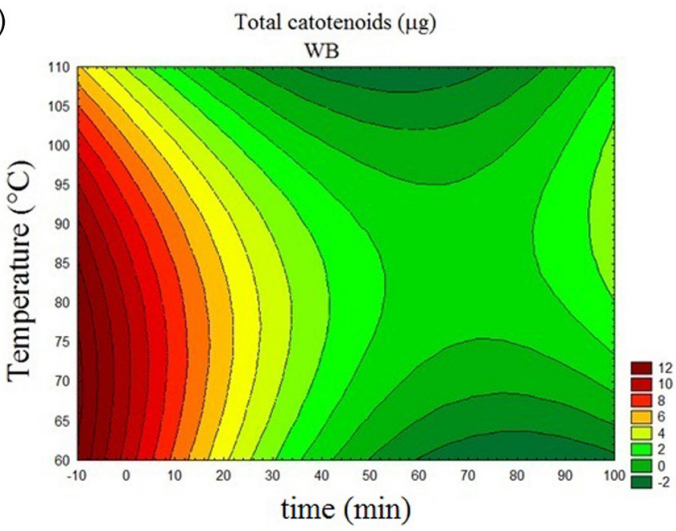

(B)
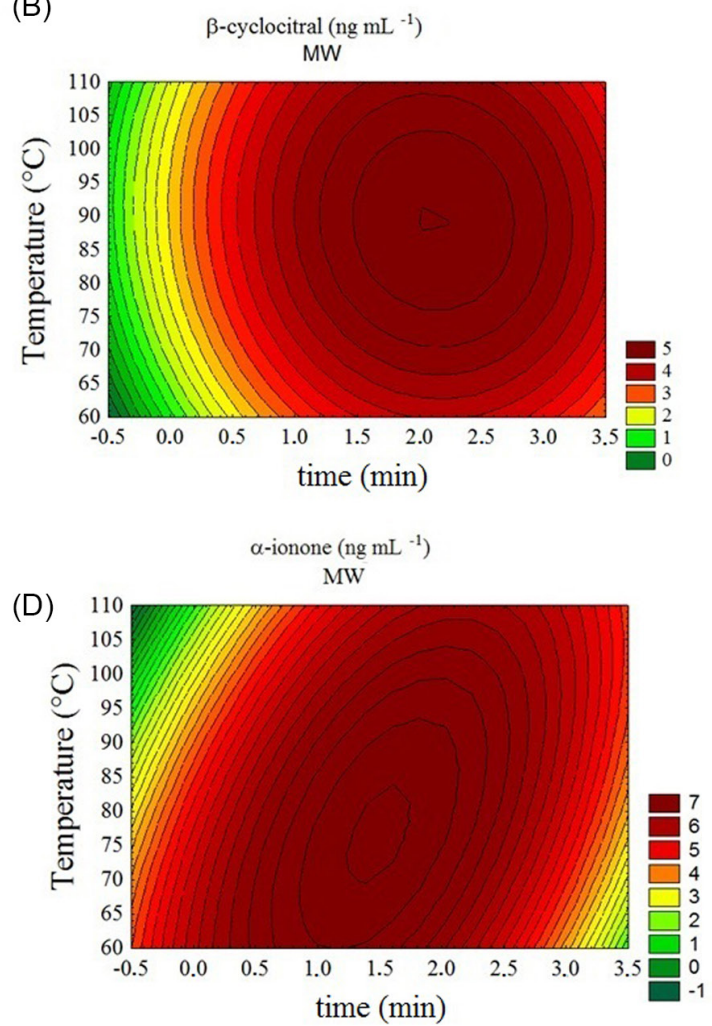

$(\mathrm{F})$

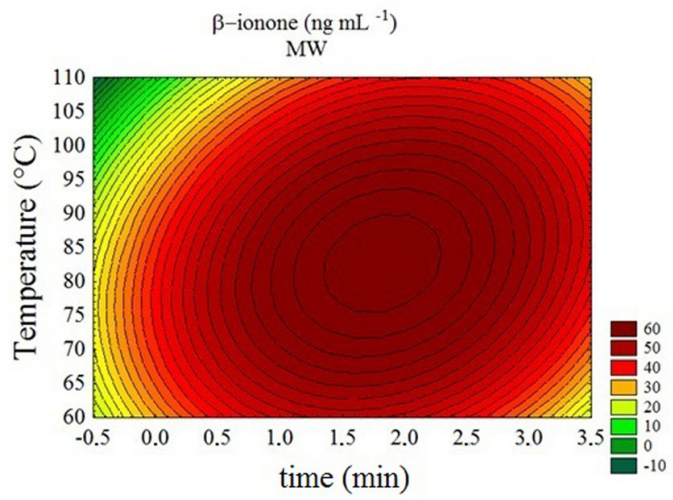

$(\mathrm{H})$

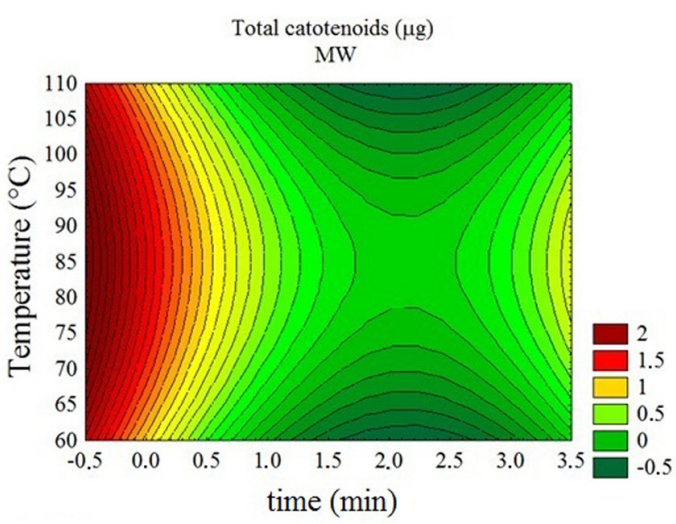

Figure 1. Contour plots for (A) $\beta$-cyclocitral WB; (B) $\beta$-cyclocitral MW; (C) $\alpha$-ionone WB; (D) $\alpha$-ionone MW; (E) $\beta$-ionone WB; (F) $\beta$-ionone MW; (G) total carotenoids WB; $(\mathrm{H})$ and total carotenoids MW as a function of temperature and time employed in the controlled degradation of carotenoids from D. bardawil. 
75-88 ${ }^{\circ} \mathrm{C}$ between 2.0-3.5 min, respectively, achieving 5, 5 and $50 \mathrm{ng} \mathrm{mL}^{-1}$ of $\beta$-cyclocitral, $\alpha$-ionone and $\beta$-ionone, respectively. Previous study ${ }^{36}$ on the production of norisoprenoids from carotenes in potato chips revealed contents of the same order of magnitude. Related to the carotenoid content, WB process imparts a complete degradation at temperatures between $75-95{ }^{\circ} \mathrm{C}$ for 50 $85 \mathrm{~min}$, while in $\mathrm{MW}$, the complete degradation occurs between $80-95^{\circ} \mathrm{C}$ for $1.7-2.5 \mathrm{~min}$.

Kanasawud and Crouzet $^{37}$ studied the kinetic degradation of $\beta$-carotene in water under sonication and saturated by oxygen. Twenty-one volatiles were observed, dihydroactinolide included, postulated to be formed from $\beta$-ionone, as well as other volatiles. A diversity of works investigated the radical oxidation of carotenoids at different conditions. More recently, Dongho et al. ${ }^{38}$ investigated carotenoid degradation caused by sunlight exposure and heating conditions in crude palm oil, revealing a significant decrease of carotenoids in accelerated heating. Interestingly, they also observed a high increase of peroxide value related to lipid oxidation, where the reactive oxygen species (ROS) produced in the process could also impact carotenoid degradation. In fact, ROS react with the polyene chain of carotenoids to generate apocarotenals and, later, norisoprenoids. ${ }^{21}$ As $D$. bardawil is rich in tri- and diacylglicerols, ${ }^{39}$ both direct heating and ROS mechanisms may contribute to norisoprenoid production.

For the time variable (minutes), WB process suggests 45 to $55 \mathrm{~min}$ for the simultaneous production of the three compounds. For MW, it was not possible to observe a common area for the production of the three compounds, but only for $\beta$-cyclocitral and $\beta$-ionone (2.3-2.8 min).

It is also interesting to observe that MW process can lead to a greater yield of volatiles when the time is the same as in the WB process. As an example, for $\beta$-cyclocitral at the center point, $1.5 \mathrm{~min}$ were necessary for $\mathrm{MW}$ and $45 \mathrm{~min}$ for WB (Table S1), to give $4.46 \pm 0.34$ and $12.83 \pm 0.11 \mathrm{ng} \mathrm{mL}^{-1}$, respectively. Therefore, 30 cycles of 1.5 min in MW would yield 10 times more $\beta$-cyclocitral at the central point conditions in both methods.

\section{Conclusions}

To the best of our knowledge, this is the first work using carotenoids from $D$. bardawil microalgae to produce volatile compounds, employing microwave irradiation and water bath controlled heating. This proposal suggests a sustainable production or enrichment of volatiles commonly present in food products, since water and mild conditions of time and temperature were employed.

\section{Supplementary Information}

Supplementary data are available free of charge at http://jbcs.sbq.org.br as PDF file.

\section{Acknowledgments}

The authors thank Prof Elis Cristina Araujo Eleutherio (Stress Factors Research Laboratory-LIFE) and Prof Barbara Vasconcellos da Silva (Laboratory of Natural Products), both from Federal University of Rio de Janeiro, the National Institute of Technology, CNPq, CAPES and FAPERJ for financial support.

\section{References}

1. Mata, T. M.; Martins, A. A.; Caetano, N. S.; Renewable Sustainable Energy Rev. 2010, 14, 217.

2. Pasquet, V.; Cherouvrier, J. R.; Farhat, F.; Thiery, V.; Piot, J. M.; Berard, J. B.; Kaas, R.; Serive, B.; Patrice, T.; Cadoret, J. P.; Picot, L.; Process Biochem. 2011, 46, 59.

3. Arad, S. M.; Varon, A.; Trends Food Sci. Technol. 1992, 3, 92.

4. del Campo, J. A.; García-González, M.; Guerrero, M. G.; Appl. Microbiol. Biotechnol. 2007, 74, 1163.

5. Gouveia, L.; Nobre, B. P.; Marcelo, F. M.; Mrejen, S.; Cardoso, M. T.; Palavra, A. F.; Mendes, R. L.; Food Chem. 2007, 101, 717.

6. Pilát, Z.; Bernatová, S.; Ježek, J.; Šerý, M.; Samek, O.; Zemánek, P.; Nedbal, L.; Trtílek, M.; J. Appl. Phycol. 2012, $24,541$.

7. Qin, S.; Lin, H.; Jiang, P.; Biotechnol. Adv. 2012, 30, 1602.

8. Rodrigues, D. B.; Flores, E. M. M.; Barin, J. S.; Mercadante, A. Z.; Jacob-Lopes, E.; Zepka, L. Q.; Food Res. Int. 2014, 65, 144.

9. Ribeiro, B. D.; Barreto, D. W.; Coelho, M. A. Z.; Food Bioprocess Technol. 2011, 4, 693.

10. Ye, Z. W.; Jiang, J. G.; Wu, G. H.; Biotechnol. Adv. 2008, 26, 352.

11. Tafreshi, A. H.; Shariati, M.; J. Appl. Microbiol. 2009, 107, 14.

12. Gómez, P. I.; Barriga, A.; Cifuentes, A. S.; Gonzáles, M. A.; Biol. Res. 2003, 36, 185.

13. Guevara, M.; Lodeiros, C.; Gómez, O.; Lemus, N.; Núñez, P.; Romero, L.; Vásquez, A.; Rosales, N.; Rev. Biol. Trop. 2005, 53,331 .

14. Orset, S.; Young, A.; J. Phycol. 1999, 35, 520.

15. Herrero, M.; Ibañez, E.; Cifuentes, A.; Reglero, G.; Santoyo, S.; J. Food Prot. 2006, 69, 2471.

16. Larroche, C.; Creuly, C.; Gros, J. B.; Appl. Microbiol. Biotechnol. 1995, 222.

17. Mendes-Pinto, M. M.; Arch. Biochem. Biophys. 2009, 483, 236. 
18. Zorn, H.; Langhoff, S.; Scheibner, M.; Berger, R. G.; Appl. Microbiol. Biotechnol. 2003, 62, 331.

19. Waché, Y.; Bosser-Deratuld, A. L.; Lhuguenot, J.; Belin, J. J.; Agric. Food Chem. 2003, 51, 1984.

20. Uenojo, M.; Pastore, G. M.; Ciênc. Tecnol. Aliment. 2010, 30, 822.

21. Havaux, M.; Plant J. 2013, 79, 597.

22. Maldonado-Robledo, G.; Rodriguez-Bustamante, E.; SanchezContreras, A.; Rodriguez-Sanoja, R.; Sanchez, S.; Appl. Microbiol. Biotechnol. 2003, 62, 484.

23. Wang, S.; Jiao, L.; Li, Y.; Fan, M.; Int. J. Food Prop. 2012, 15, 1381.

24. Donadio, C.; Bialecki, A.; Valla, A.; Dufossé, L.; J. Food Comp. Anal. 2011, 24, 801.

25. Tsukui, A.; Rezende, C. M.; Rev. Virtual Quim. 2014, 6, 1713.

26. Dahmoune, F.; Spigno, G.; Moussi, K.; Remini, H.; Cherbal, A.; Madani, K.; Ind. Crop. Prod. 2014, 61, 31.

27. Menezes, M. F. S. C.; Simeoni, C. P.; Poletto, G.; Barin, J. S.; Cichoski, A. J.; Menezes, C. R.; REGET. 2014, 18, 90.

28. Shaish, A.; Ben-Amotz, A.; Avron, M.; Methods Enzymol. 1992, $213,439$.

29. Viegas, M. C.; Bassoli, D. G.; Quim. Nova 2007, 30, 2031.

30. Moniruzzaman, M.; Rodríguez, I.; Ramil, M.; Cela, R.; Sulaiman, S. A.; Gan, S. H.; Talanta 2014, 129, 505.
31. Instituto Nacional de Metrologia, Normalização e Qualidade Industrial (INMETRO); DOQ-CGCRE-008: Orientações sobre Validação de Métodos de Ensaios Químicos, 2011.

32. Massart, D. L.; Vandeginste, B. G. M.; Buydens, L. M. C.; de Jong, S.; Lewi, P. J.; Smeyers-Verbeke, J.; Handbook of Chemometrics and Qualimetrics: Part A, vol. 20A; Elsevier Science B.V.: Amsterdam, 1997.

33. Lichtenthaler, H. K.; Methods Enzymol. 1987, 148, 350.

34. Brotas, V.; Plante-Cuny, M.; Acta Oecol. 2003, 24, 109.

35. Nonier, M.; de Gauleja, N. V.; Vivas, N.; Vitry, C.; C. R. Chim. 2004, 7, 689.

36. Bechoff, A.; Dhuique-Mayer, C.; Dornier, M.; Tomlins, K. I.; Boulanger, R.; Dufour, D.; Westby, A.; Food Chem. 2010, 121, 348.

37. Kanasawud, P.; Crouzet, J. C.; J. Agric. Food Chem. 1990, 38, 237.

38. Dongho, D. F. F.; Annie, N. N.; Adélaide, D. M.; Florian, S.; Inocent, G.; J. Food Process. Technol. 2014, 5, 314.

39. Oncel, S. S.; Renewable Sustainable Energy Rev. 2013, 26, 241.

Submitted: January 31, 2016

Published online: June 1, 2016 